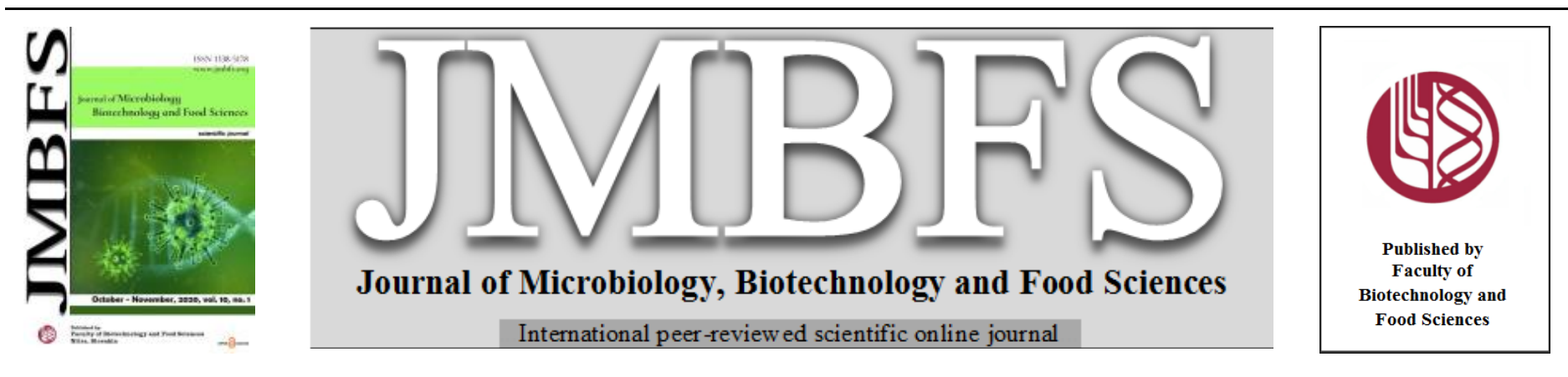

\title{
THE EFFECT OF APRICOT SEEDS ON MICROSCOPIC STRUCTURE OF RABBIT LIVER
}

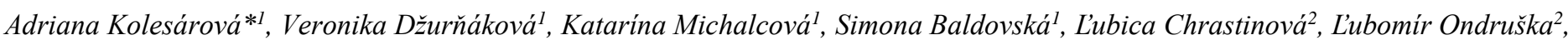

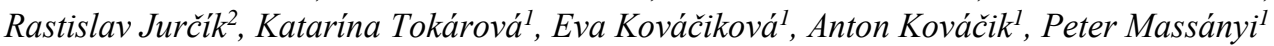

Address(es): prof. Ing. Adriana Kolesárová, PhD.,

${ }^{1}$ Slovak University of Agriculture in Nitra, Faculty of Biotechnology and Food Sciences, Department of Animal Physiology, Tr. A. Hlinku 2, 94976 Nitra, Slovak Republic, phone number: +421-37-641 4119.

${ }^{2}$ National Agricultural and Food Centre, Luzianky, Research Institute for Animal Production Nitra, Institute of Small Farm Animals, Hlohovecka 2, 95141 Luzianky, Slovak Republic.

*Corresponding author: Adriana.Kolesarova@uniag.sk

doi: 10.15414/jmbfs.2020.10.2.321-324

ARTICLE INFO

Received 15. 4. 2020

Revised 24. 6. 2020

Accepted 30. 6. 2020

Published 1. 10. 2020

Regular article

open $\partial_{\text {ACCESS }}$

\begin{abstract}
Natural phytosubstances, such as amygdalin, used in alternative medicine has gained popularity. However, some researchers suspect the protective properties of amygdalin due to a lack of clinical studies. The aim of the present in vivo study was to determine the effect of apricot seed administration on microscopic changes in the liver using a rabbit as a biological model. Sixteen male rabbits 45 days old were randomly divided into four groups (control group without any apricot seed administration, and experimental groups fed by crushed apricot seeds at the doses 60,300 and $420 \mathrm{mg} / \mathrm{kg}$ b.w., mixed with commercial feed), which was administered orally a daily during a ten-month period. The liver tissue samples were evaluated by histological analysis. Significant changes were observed in the microscopic structure of rabbit livers after apricot seed ingestion. The morphometric evaluation of rabbit livers after the application of apricot seeds showed an increase of binucleated cells in the vena centralis region $(\mathrm{P} \leq 0.001)$ at the highest dose and in the peripheral zone at all the doses used $(\mathrm{P} \leq 0.001, \mathrm{P} \leq 0.01, \mathrm{P} \leq 0.05)$ compared to control. On the other hand, distinct inhibition in the number of binucleated cells in the region vena centralis at the doses $300(\mathrm{P} \leq 0.01)$ and $420 \mathrm{mg} / \mathrm{kg}$ b.w. $(\mathrm{P} \leq 0.05)$ and in the peripheral zone at all the doses used $(\mathrm{P} \leq 0.001, \mathrm{P} \leq 0.01)$ was observed. No significant differences between the control and experimental groups in vena centralis after apricot seed treatment were found $(\mathrm{P} \geq 0.05)$. In addition, the effect of apricot seeds on the relative volume of liver structures - vena centralis, stroma and parenchyma after the application of apricot seeds to rabbit males were assessed. No significant differences between control and experimental groups in the relative volume of vena centralis were found $(\mathrm{P} \geq 0.05)$. On the other hand, the relative volume of the stroma was increased at doses $60(\mathrm{P} \leq 0.05)$ and $300(\mathrm{P} \leq 0.01) \mathrm{mg} / \mathrm{kg}$ b.w. Interestingly, the relative volume of parenchyma was significantly decreased $(\mathrm{P} \leq 0.05)$ after the application of apricot seeds in two experimental groups 60 and $300 \mathrm{mg} / \mathrm{kg}$ b.w. The current study provides experimental evidence that apricot seeds might affect the liver microscopic structure in rabbits in vivo and thus amygdalin present in apricot seeds might present a potential risk for animal health. However, the toxic effect could not be accurately corroborated, as in many cases changes were dose-dependent and not recorded at the highest dose used in the study.
\end{abstract}

Keywords: amygdalin, apricot seed, liver, rabbit

\section{INTRODUCTION}

The field of nutritional research focuses on phytonutrients and their beneficial properties on health. Phytonutrients, which include in particular polyphenols, flavonoids (isoquercitrin, rutin, quercetin, and others) (Roychoudhury et al. 2018; Kolesarova et al., 2019), ellagitannins, especially punicalagin and ellagic acid (Packova et al., 2015), glycosides (amygdalin) (Halenar et al., 2015, 2017; Kolesar et al., 2018; Kopcekova et al., 2018; Kovacikova et al., 2019) and others are known to possess potential antioxidant and antitumor activity and the ability to eliminate environmental stress-induced reprotoxicity (Kolesarova et al., 2012; Halenar et al., 2015).

Cancer is a major public health problem worldwide and is the second leading cause of death in the United States (Siegel et al., 2018). Despite advances in radiotherapy and chemotherapy, problems related to these therapies such as side effects and development of drug resistance remained unsolved (Rogers $\boldsymbol{e t}$ al. 2012). One of the strategies to solve these problems is to develop novel therapies. In the research for the alternative therapies for cancer treatment, it has been noticed that a natural cyanide-containing substance, amygdalin (AMG), has a gaining reputation as a complementary substance for cancer treatment due to its effectiveness in inhibiting the growth of cancer cells and easy availability (Chang et al., 2006; Park et al., 2005).

Amygdalin is found in the family Rosaceae, especially in apricot seeds and almonds which contain vitamins, carbohydrates, organic acids, esters, phenols, terpenoids, except cyanogenic glycoside in the seeds (Michalcová et al., 2016).
Amygdalin (D-mandelonitrile- $\beta$-D-glucoside-6- $\beta$-D-glucoside), a natura substance used in alternative medicine for its many beneficial properties (Tanwar et al., 2019), is a cyanogenic glycoside plant toxin contained in relatively high concentrations in the kernels and seeds of apples, apricots, almonds, cherries, and peaches, and it is abundant in plum seeds (Lee $\boldsymbol{e t}$ al. 2017). Seeds contain amygdalin depending on the variety: approximately 20$80 \mu \mathrm{mol} / \mathrm{g}$ AMG may be found in apricot seeds, and its concentration is very high $(5.5 \mathrm{~g} / 100 \mathrm{~g})$ in bitter apricot cultivars while it is not detected in the sweet ones (Kolesar et al., 2018). Amygdalin is composed of two molecules of glucose, one molecule of benzaldehyde, and one molecule of hydrocyanide. Amygdalin could be a new therapeutic substance for cancer patients although there has been controversy surrounding the use of AMG as a cancer drug due to concerns of cyanide toxicity (Chen et al., 2013).

The present study was designed to reveal the effects of apricot seed administration at the doses of 60,300 and $420 \mathrm{mg} / \mathrm{kg}$ on microscopic changes in the liver of rabbits in vivo.

\section{MATERIAL AND METHODS}

\section{Animals}

For the purpose of this study rabbits of meat line P91 (Californian rabbit) from the experimental farm of the Research Institute for Animal Production Nitra (Slovak Republic) were used. The rabbits were housed in breeding cages for 
laboratory rabbits in daylight mode $12 \mathrm{~h}$ light/12 $\mathrm{h}$ dark, at a temperature ranging $20-24{ }^{\circ} \mathrm{C}$ and humidity $55 \pm 10 \%$. All animals had permanent access to water during the experimental ten-month period, which was secured by automatic feeders. Daily amounts of feed (200 g) were administered to the animals, and the rest of the feed was regularly recorded. Conditions of animal care, manipulations, and use corresponded with the instructions of the institutional ethical commission. Care and use of animals and experimental devices met the requirements for the certificate of Authorization to Experiment on Living Animals no. 3398/11-221/3 (certified by State Veterinary and Food Institute of the Slovak Republic). All efforts were made to minimize the suffering of animals.

\section{Application of apricot seeds}

Bitter apricot seeds were provided by Trasco (Žiar n. Hronom, Slovakia). Thin Layer Chromatography (TLC) was performed for the analysis of amygdalin content in bitter apricot seeds used in our experiment. The chemical composition of the apricot seeds was carried out (Halenar et al., 2017). Animals 45 days old were randomly divided into four groups (C-control, P1, P2, P3-experimental groups) leading to 4 male rabbits in each group. The control group received no apricot seeds while the experimental groups $\mathrm{P} 1, \mathrm{P} 2$, and $\mathrm{P} 3$ received a daily dose of 60,300 and $420 \mathrm{mg} / \mathrm{kg}$ b.w. of crushed apricot seeds mixed with feed. Apricot seeds were crushed and processed into a commercially available granulated feed, which was administered orally a day for 10 months. The first experimental group of rabbits was given the lowest dose of $60 \mathrm{mg} / \mathrm{kg}$ b.w., the dose of $300 \mathrm{mg} / \mathrm{kg}$ b.w. to the second experimental group, and a dose of $420 \mathrm{mg} / \mathrm{kg}$ b.w. of aprico seeds to the third experimental group of animals. After 10 months of in vivo apricot seed administration, the animals (weighing $4.0 \pm 0.5 \mathrm{~kg}$ ) were sacrificed by electric stunning and subsequent bleeding at the Research Institute for Animal Production Nitra (Slovak Republic).

\section{Histopathological analysis}

For histopathological examinations, the liver tissue samples $(\mathrm{n}=16)$ were fixed in $10 \%$ neutral buffered formalin (Sigma-Aldrich), dehydrated with ethanol (70\% and $96 \%$ for $2 \mathrm{~h}$ and $100 \%$ for $1 \mathrm{~h}$ ) and embedded in paraffin wax. The samples were cut using rotary microtome AC-820 (American Corporation, USA) and stained with a buffered solution of basic fuchsin with toluidine blue, diluted in a ratio of 3:2 (Bourne and St. John, 1978). Stained sections were mounted in Entelan and examined under an optical microscope fitted with a camera (Olympus AX 70) with installed software for analysis of image M.I.S. Quick Photo at a magnification of $10 \times 40$ and 20x40. The basic morphometric criteria of the preparations were quantified using image program MeasureIT (Olympus, Japan). Structural assessment of the liver was carried out by morphometric parameters in a selected area around the vena centralis $(934.4 \mu \mathrm{m}$ and 69,594.1 $\mu \mathrm{m} 2$, respectively) and the peripheral zone (1302.4 $\mu \mathrm{m}$ and 104,215.2 $\mu \mathrm{m} 2$, respectively).

\section{Statistical analysis}

Statistical analysis was carried out using the Graph Pad Prism program (version 3.02 for Windows; GraphPad Software, La Jolla California USA, www.graphpad.com). Descriptive statistical characteristics (mean, standard erro of the mean) were evaluated at first. One-way ANOVA was used for specific statistical evaluation. Dunnett's test was used as a follow-up test to ANOVA, based on a comparison of every mean to control mean, and computing a confidence interval for the difference between the two means. The levels of significance were set at $\mathrm{P} \leq 0.05, \mathrm{P} \leq 0.01$, and $\mathrm{P} \leq 0.001$.

\section{RESULTS AND DISCUSSION}

Amygdalin is one of the main biologically active substances present in apricot seeds, hot almonds, flax seeds, and others (Tanwar et al., 2019). The effect of AMG present in apricot seeds has been partially described in our previous studies using the porcine model (Halenar et al., 2015), rabbits (Halenar et al., 2017; Kolesar et al., 2018; Kovacikova et al., 2019) and humans (Kopčeková et al., 2018; Kovacikova et al., 2017). The objective of this study was to evaluate the effects of apricot seeds on microscopic characteristics of rabbit liver in vivo.

The effect of apricot seeds on the microscopic structure of rabbit liver after oral application of apricot seeds at the doses of 60,300 and $420 \mathrm{mg} / \mathrm{kg}$ b.w. for ten months was examined. Binucleated cells in the vena centralis region and the peripheral zone are shown in Figs. 1-5. The relative representation of structures of the liver - vena centralis, stroma and parenchyma are given in (Figs. 6-8).

The effect of apricot seeds on the morphometric evaluation of rabbit liver after application of apricot seeds on young rabbit males was assessed in this in vivo study (Figs. 1-5). A distinct increase $(\mathrm{P} \leq 0.001)$ was observed in the number of binucleated cells in the vena centralis region and the peripheral zone at the highest dose compared to control (Fig. 1,4). Likewise, a slight increase was observed at the two lowest doses of apricot seeds compared to control $(\mathrm{P} \leq 0.01$, $\mathrm{P} \leq 0.05$; Fig.4). On the contrary, there was a distinct inhibition in the number of binucleated cells in the region of vena centralis and the peripheral zone (Fig. 3 ,
5). A significant decrease was shown at doses $300(\mathrm{P} \leq 0.01)$ and $420 \mathrm{mg} / \mathrm{kg}$ b.w. $(\mathrm{P} \leq 0.05$; Fig. 3), and also at the doses $60(\mathrm{P} \leq 0.01), 300(\mathrm{P} \leq 0.001)$, and 420 $(\mathrm{P} \leq 0.01) \mathrm{mg} / \mathrm{kg}$ b.w. compared to the control group (Fig. 5). No significant differences between the control and experimental groups were noted in vena centralis after apricot seed treatment. There was moderate stimulation in all experimental groups, but the results were not conclusive (Fig. 2).

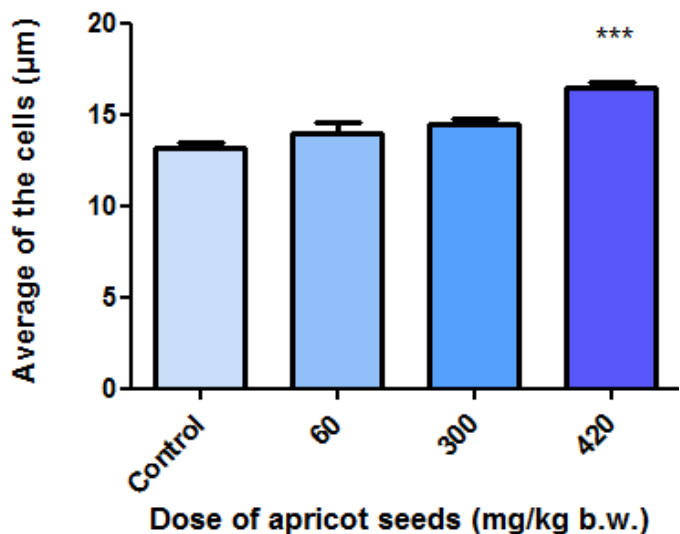

Figure 1 Binucleated cells in the vena centralis region after feeding the male rabbits with apricot seeds for 10 months. The control group represents rabbits without the application of apricot seeds. Experimental groups with apricot seeds at doses 60,300 and $420 \mathrm{mg} / \mathrm{kg}$ b.w. Significant differences $(* * * \mathrm{P}<0.001)$ between control and experimental groups were evaluated by One-way ANOVA (Dunnett's test). Data are expressed as means \pm SEM. Histology.

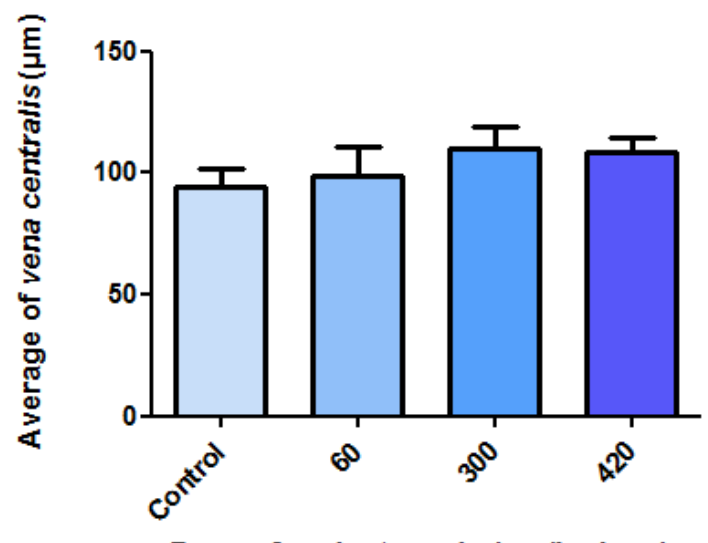

Figure 2 Vena centralis diameter after feeding the male rabbits with apricot seeds for 10 months. The control group represents rabbits without the application of apricot seeds. Experimental groups with apricot seeds at doses 60, 300 and 420 $\mathrm{mg} / \mathrm{kg}$ b.w. Differences between control and experimental groups were evaluated by One-way ANOVA (Dunnett's test). Data are expressed as means \pm SEM. Histology.

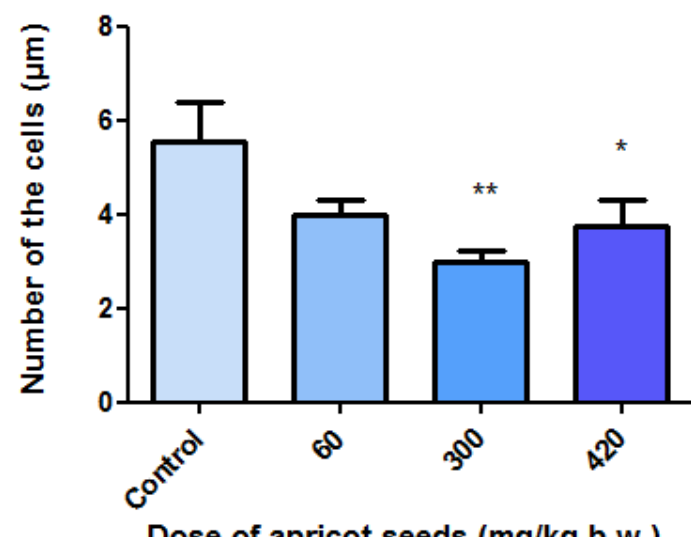

Figure 3 Binucleated cells in the vena centralis region after feeding the male rabbits with apricot seeds for 10 months. The control group represents rabbits without the application of apricot seeds. Experimental groups with apricot seeds at doses 60, 300 and $420 \mathrm{mg} / \mathrm{kg}$ b.w. Significant differences $(* * \mathrm{P}<0.01$, * $\mathrm{P}<0.05)$ between control and experimental groups were evaluated by One-way ANOVA (Dunnett's test). Data are expressed as means \pm SEM. Histology. 


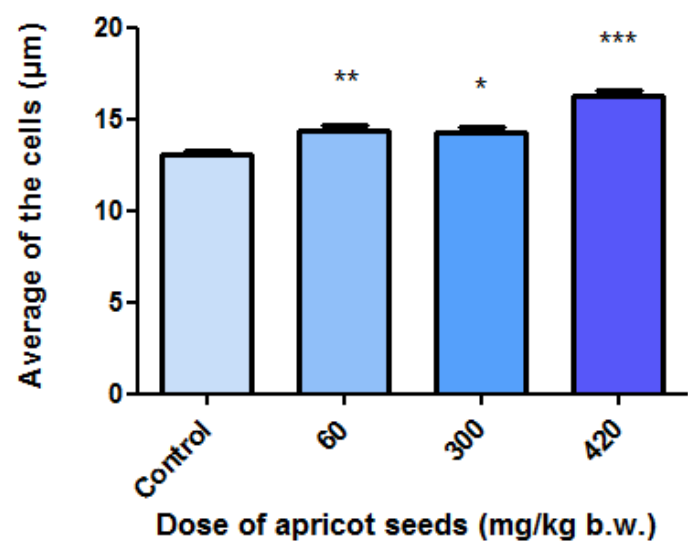

Figure 4 Binucleated cells in the peripheral zone after feeding the male rabbits with apricot seeds for 10 months. The control group represents rabbits without the application of apricot seeds. Experimental groups with apricot seeds at doses 60,300 and $420 \mathrm{mg} / \mathrm{kg}$ b.w. Significant differences (***P $<0.001$, ** $\mathrm{P}<0.01$, * $\mathrm{P}<0.05$ ) between control and experimental groups were evaluated by One-way ANOVA (Dunnett's test). Data are expressed as means \pm SEM. Histology.

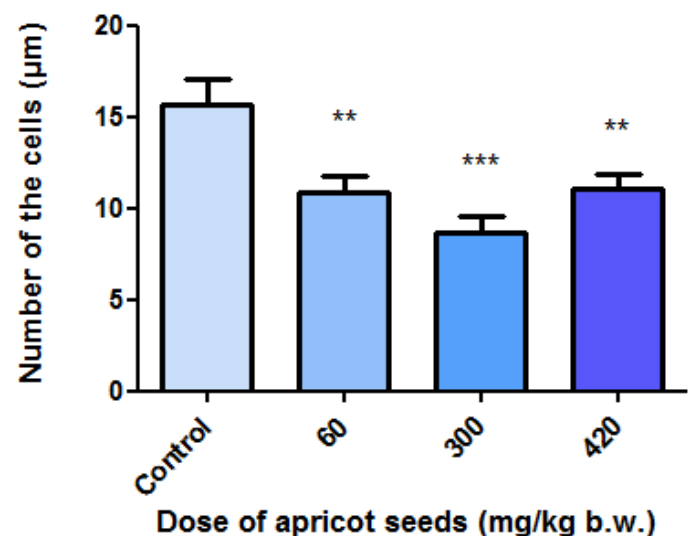

Figure 5 Binucleated cells in the peripheral zone after feeding the male rabbits with apricot seeds for 10 months. The control group represents rabbits without the application of apricot kernels. Experimental groups with apricot kernels at doses 60,300 and $420 \mathrm{mg} / \mathrm{kg}$ b.w. Significant differences $(* * * \mathrm{P}<0.001$, $* * \mathrm{P}<0.01$ ) between control and experimental groups were evaluated by One-way ANOVA (Dunnett's test). Data are expressed as means \pm SEM. Histology.

The effect of apricot seeds administration on the relative volume of structures of rabbit liver - vena centralis, stroma and parenchyma were assessed in this in vivo study (Figs. 6-8). No significant $(\mathrm{P} \geq 0.05)$ difference was found between control and experimental groups in the relative volume of vena centralis, although a moderate inhibition in two experimental groups of 300 and $420 \mathrm{mg} / \mathrm{kg}$ b.w. was observed as compared to the control group without the addition of natural substance (Fig. 6). Significant differences were found in the relative volume of stroma between control and experimental groups $60(\mathrm{P} \leq 0.05)$ and $300(\mathrm{P} \leq 0.01)$ $\mathrm{mg} / \mathrm{kg}$ b.w. (Fig. 7). On the other hand, a significant $(\mathrm{P} \leq 0.05)$ inhibition of relative volume of parenchyma was noted after the application of apricot seeds in two experimental groups 60 and $300 \mathrm{mg} / \mathrm{kg}$ b.w. in comparison to control (Fig. 8).

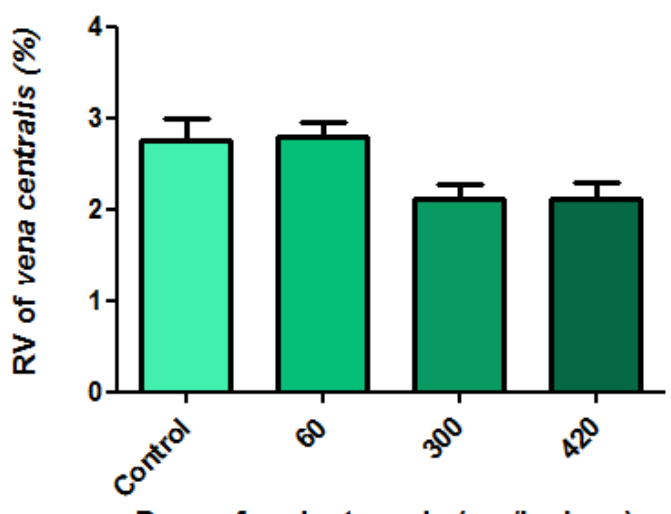

Dose of apricot seeds ( $\mathrm{mg} / \mathrm{kg}$ b.w.)

Figure 6 The relative volume of vena centralis after feeding the male rabbits with apricot seeds for 10 months. The control group represents rabbits without the application of apricot seeds. Experimental groups with apricot seeds at doses 60,300 and $420 \mathrm{mg} / \mathrm{kg}$ b.w. Differences between control and experimental groups were evaluated by One-way ANOVA (Dunnett's test). Data are expressed as means \pm SEM. Histology.

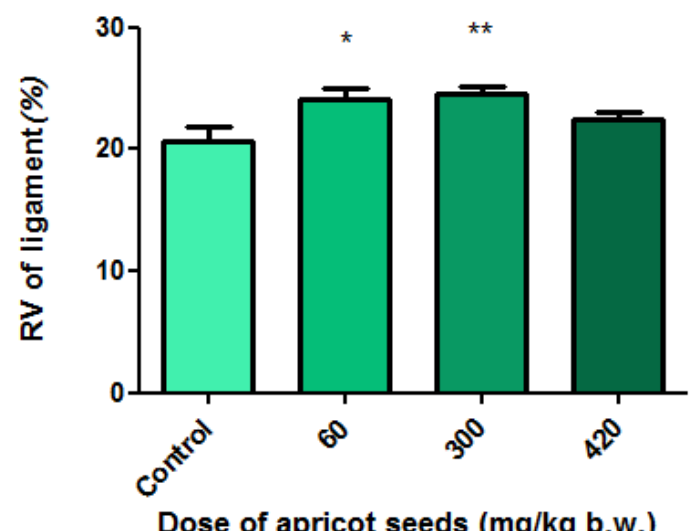

Figure 7 The relative volume of stroma after feeding the male rabbits with apricot seeds for 10 months. The control group represents rabbits without the application of apricot seeds. Experimental groups with apricot seeds at doses 60 , 300 and $420 \mathrm{mg} / \mathrm{kg}$ b.w. Significant differences $(* * \mathrm{P}<0.01, * \mathrm{P}<0.05)$ between control and experimental groups were evaluated by One-way ANOVA (Dunnett's test). Data are expressed as means \pm SEM. Histology.

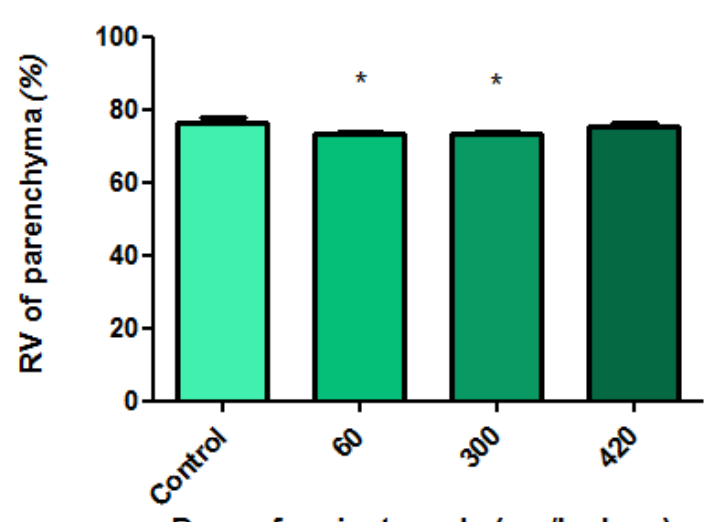

Dose of apricot seeds ( $\mathrm{mg} / \mathrm{kg}$ b.w.)

Figure 8 The relative volume of parenchyma after feeding the male rabbits with apricot seeds for 10 months. The control group represents rabbits without the application of apricot seeds. Experimental groups with apricot seeds at doses 60, 300 and $420 \mathrm{mg} / \mathrm{kg}$ b.w. Significant differences $(* \mathrm{P}<0.05)$ between control and experimental groups were evaluated by One-way ANOVA (Dunnett's test). Data are expressed as means \pm SEM. Histology.

In the current study, the effect of apricot seeds on the microscopic structure of the rabbit liver was investigated. Apricot seeds containing the active ingredient AMG have found widespread use in the treatment of many diseases. There have been several hypotheses that it kills tumour cells selectively at the site of their proliferation without systemic toxicity and can effectively relieve pain in cancer patients (Michalcová et al., 2016). They investigated the effect of AMG present in apricot seeds on the concentration of blood plasma hormones of male and female rabbits in vivo at doses 60,300 and $420 \mathrm{mg} / \mathrm{kg}$ b.w. of apricot seeds, which were administered to rabbits orally. The lowest dose of apricot seeds showed a slight increase of prolactin (PRL) concentrations in the blood plasma $(\mathrm{P} \geq 0.05)$ of males. No significant $(\mathrm{P} \geq 0.05)$ difference was observed in the case of PRL and LH levels in the blood plasma of females. On the other hand, a significant $(\mathrm{P} \leq 0.05)$ inhibition of $\mathrm{FSH}$ release was induced by seeds at the doses of $300,420 \mathrm{mg} / \mathrm{kg}$ b.w.

Another study examined the inhibitory effects of AMG in itself and activated with $\beta$-d-glucosidase on the proliferation of the investigated HepG2 cells Compared with AMG, the activated ingredients showed a stronger inhibitory effect on the proliferation rate among the cells tested. The findings indicate that AMG had no strong anti-HepG2 activity, however, the ingredients of AMG activated with $\beta$-D-glucosidase had a higher and efficient anti-HepG2 activity. It was, therefore, suggested that this combination strategy may be applicable for treating tumours with a higher activity (Zhou et al., 2012).

Chang et al. (2006) stated that despite the significant effects of AMG, the Food and Drug Administration (FDA) has not approved it in cancer treatment owing to insufficient clinical evidence of efficacy and potential toxicity of AMG. Despite the failure of clinical tests to demonstrate the anticancer effects of AMG in the USA and in Europe, it continues to be manufactured and administered as an 
anticancer therapy in northern Europe and Mexico (Chang et al., 2006; Kwon $\boldsymbol{e}$ al., 2010). The effect of AMG is generally known in the treatment of cancer According to Arshi et al. (2019), AMG an anti-cancer effect on human cancer cell lines, where AMG significantly inhibits the expression level of two antiapoptotic genes (Survivin, XIAP), showing potential as a natural therapeutic anticancer drug. Some of the studies showed the inhibition of tumour cell growth by AMG (Juengel et al., 2016; Makarević et al., 2014; 2016).

Other studies have also described AMG toxicity. It is known that the harmfu effects of apricot seeds are associated with the cyanide toxicity that is released upon hydrolysis of AMG. According to Adewusi and Oke (1985), AMG toxicity due to cyanide release requires the activity of intestinal microflora. The current review highlights apoptosis-inducing attributes of AMG towards different cancers and its potential application as an anti-cancer agent in cancer therapy. However, well-planned clinical trials are still needed to prove the effectiveness of this substance in vivo and for its approval for human use (Saleem et al., 2018).

\section{CONCLUSION}

Based on the findings, it may be concluded that apricot seeds administered orally to experimental animals had a modulating effect on the microscopic structure of rabbit liver in vivo. However, the toxic effect can not be accurately corroborated as in many cases the changes were not recorded at the highest dose used in the study. It is necessary to evaluate the blood parameters particularly hematologica and biochemical indicators, including liver enzymes, which might help in either confirming or refuting the toxicity of apricot seeds. Our results suggest that 10 months of consumption of apricot seeds affected the microscopic structure of the liver cells of male rabbits, but as the liver is an organ with a high regenerative capacity, we assume that these dose-dependent changes may also be are reversible.

Acknowledgments: This work was supported by the Ministry of Education, Science, Research and Sport of the Slovak Republic projects APVV-18-0312, DS-FR-19-0049, VEGA 1/0266/20, The Excellent scientific team "Center of Animal Reproduction (CeRA)", and AgroBioTech Research Centre built in accordance with the project Building „AgroBioTech" Research Centre ITMS 26220220180 .

\section{REFERENCES}

ADEWUSI, S. R., OKE, O. L. 1985. On the metabolism of amygdalin. 2. The distribution of beta-glucosidase activity and orally administered amygdalin in rats. Canadian Journal of Physiology and Pharmacology, 63(9), 1084-1087. http://doi.org/10.1139/y85-178

ARSHI, A., HOSSEINI, S. M., HOSSEINI, F. S. K., AMIRI, Z. Y., HOSSEINI, F. S., SHEIKHOLIA LAVASANI, M., KERDARIAN, H., DEHKORDI, M. S 2019. The anti-cancer effect of amygdalin on human cancer cell lines. Molecular biology reports, 46(2), 2059-2066. http://doi.org/10.1007/s11033-019-04656-3

CHANG, H. K., SHIN, M. S., YANG, H. Y., LEE, J. W., KIM, Y. S., LEE, M H., KIM, J., KIM, K. H., KIM, C. J. 2006. Amygdalin induces apoptosis through regulation of Bax and $\mathrm{Bcl}-2$ expressions in human DU145 and $\mathrm{LNCaP}$ prostate cancer cells. Biological and Pharmaceutical Bulletin, 29(8),1597-1602. https://doi.org/10.1248/bpb.29.1597

CHEN, Y., MA, J., WANG, F., HU, J., CUI, A., WEI, C., YANG, Q., LI, F. 2013. Amygdalin induces apoptosis in human cervical cancer cell line HeLa cells. Immunopharmacology and Immunotoxicology, 35(1), 43-51. http://doi.org/10.3109/08923973.2012.738688

HALENAR, M., CHRASTINOVA, L., ONDRUSKA, L., JURCIK, R., ZBYNOVSKA, K., TUSIMOVA, E., KOVACIK, A. KOLESAROVA, A. 2017. The evaluation of endocrine regulators after intramuscular and oral application of cyanogenic glycoside amygdalin in rabbits. Biologia, 72(4), 468-474. ISSN13369563.

HALENAR, M., MEDVEDOVA, M., MARUNIAKOVA, N., KOLESAROVA, A. 2015. Assessment of a potential preventive ability of amygdalin in mycotoxininduced ovarian toxicity. Journal of Environmental Science and Health B, 50(6) 411-6. https://doi.org/10.1080/03601234.2015.1011956

JUENGEL, E., THOMAS, A., RUTZ, J., MAKAREVIC, J., TSAUR, I., NELSON, K., HAFERKAMP, A., BLAHETA, R. A. 2016. Amygdalin inhibits the growth of renal cell carcinoma cells in vitro. International Journal of Molecular Medicine, 37(2), 526-532. http://doi.org/10.3892/ijmm.2015.2439

KOLESAR, E., TVRDA, E., HALENAR, M., SCHNEIDGENOVA, M., CHRASTINOVA, L., ONDRUSKA, L., JURCIK, R., KOVACIK, A., KOVACIKOVA, E., MASSANYI, P., KOLESAROVA, A. 2018. Assessment of rabbit spermatozoa characteristics after amygdalin and apricot seeds exposure in vivo. Toxicology Reports, $\quad$ 5, 679-686. http://doi.org/10.1016/j.toxrep.2018.05.015

KOLESAROVA, A., CAPCAROVA, M., MARUNIAKOVA, N., LUKAC, N., CIERESZKO, R. E., SIROTKIN, A. V. 2012. Resveratrol inhibits reproductive toxicity induced by deoxynivalenol. Journal of Environmental Science and Health Part A, Toxic/Hazardous Substances \& Environmental Engineering, 47(9), 1329-1334. https://doi.org/10.1080/10934529.2012.672144
KOLESAROVA, A., ROYCHOUDHURY, S., KLINEROVA, B., PACKOVA, D., MICHALCOVA, K., HALENAR, M., KOPCEKOVA, J., MNAHONCAKOVA, E., GALIK, B. 2019. Dietary bioflavonoid quercetin modulates porcine ovarian granulosa cell functions in vitro. Journal of Environmental Science and Health $\quad$ B, $1-5$. https://doi.org/10.1080/03601234.2019.1586034

KOPČEKOVÁ, J. KOLESÁROVÁ, A., KOVÁČIK, A., KOVÁČIKOVÁ, E., GAŽAROVÁ, M, CHLEBO, P., VALUCH, J., KOLESÁROVÁ, A. 2018. Influence of long-term consumption of bitter apricot seeds on risk factors for cardiovascular diseases. Journal of Environmental Science and Health B, 53(5), 298-303. https://doi.org/10.1080/03601234.2017.1421841

KOVACIKOVA, E., KOVACIK, A., HALENAR, M., MICHALCOVA, K., ZBYNOVSKA, K., KOLESAROVA, A., KOPCEKOVÁ, J., VALUCH, J., KOLESAROVA, A. 2017. Does apricot seeds consumption cause changes in humanurine? Potravinárstvo, 11(1). https://doi.org/10.5219/755

KOVACIKOVA, E., KOVACIK, A., HALENAR, M., TOKAROVA, K., CHRASTINOVA, L., ONDRUSKA, L., JURCIK, R., KOLESAR, E., VALUCH, J., KOLESAROVA, A. 2019. Potential toxicity of cyanogenic glycoside amygdalin and bitter apricot seed in rabbits-Health status evaluation. Journal of Animal Physiology and Animal Nutrition, 103(2), $695-703$ https://doi.org/10.1111/jpn.13055

KWON, H. J., LEE, J. H., HONG, S. P. 2010. Improvement of the extraction efficiency of D-amygdalin from Armeniacae Semen powder through inactivating emulsion and suppressing the epimerization of D-amygdalin. Archives of Pharmaca research, 33(1), 81-86. http://doi.org/10.1007/s12272-010-2229-3

LEE, S.H., OH, A., SHIN, S.H., KIM, H.N., KANG, W.W., CHUNG, S.K. 2017 Amygdalin contents in peaches at different fruit development stages. Preventive Nutrition and Food Science, 22(3), 237-240. http://doi.org/10.3746/pnf.2017.22.3.237

MAKAREVIĆ, J., RUTZ, J., JUENGEL, E., KAULFUSS, S., REITER, M TSAUR, I., BARTSCH, G., HAFERKAMP, A., BLAHETA, R. A. 2014 Amygdalin blocks bladder cancer cell growth in vitro by diminishing cyclin A and cdk2. Public Library of Science PLoSOne, 9(8), e105590. http://doi.org/10.1371/journal.pone.0105590

MAKAREVIĆ, J., TSAUR, I., JUENGEL, E., BORGMANN, H., NELSON, K. THOMAS, C., BARTSCH, G., HAFERKAMP, A., BLAHETA, R. A. 2016. Amygdalin delays cell cycle progression and blocks growth of prostate cancer cells in vitro. Life Sciences, 147, 137-42. http://doi.org/10.1016/j.lfs.2016.01.039 MICHALCOVÁ, K., HALENÁR, M., TUŠIMOVÁ, E., KOVÁČIK, A., CHRASTÍNOVÁ, L', ONDRUŠKA, L', JURČÍK, R., KOLESÁR, E., KOLESÁROVÁ, A. 2016. Influence of Apricot Kernels on Blood Plasma Levels of Selected Anterior Pituitary Hormones in Male and Female Rabbits in vivo. Scientific Papers: Animal Science and Biotechnologies, 49 (1), 1841-9364. ISSN 2344-4576.

PACKOVA, D., CARBONELL-BARRACHINA, A. A., KOLESAROVA, A. 2015. Ellagitannins - compounds from pomegranate as possible effector in steroidogenesis of rabbit ovaries. Physiological Research, 64, 583-585. ISSN 0862-8408.

PARK, H. J., YOON, S.H., HAN, L.S., ZHENG, L.T., JUNG, K.H., UHM, Y.K., LEE, J.H., JEONG, J.S., JOO, W.S., YIM, S.V., CHUNG, J.H., HONG, S.P 2005. Amygdalin inhibits genes related to cell cycle in SNU-C4 human colon cancer cells. World Journal of Gastroenterology, 11(33), 51565161.http://doi.org/10.3748/wjg.v11.i33.5156

ROGERS, L., SIU, S.S., LUESLEY, D., BRYANT, A., DICKINSON, H.O 2012. Radiotherapy and chemoradiation after surgery for early cervical cancer. Cochrane Database Syst Rev., 16, 5-9. http://doi.org/10.1002/14651858

ROYCHOUDHURY, S., HALENAR, M., MICHALCOVA, K., NATH, S., KACANIOVA, M., KOLESAROVA, A. 2018. Green tea extract affects porcine ovarian cell apoptosis. Reproductive Biology, 18(1), 94-98. https://doi.org/10.1016/j.repbio.2018.01.007

SALEEM, M., ASIF, J., SALEEM, U. 2018. Amygdalin from apricot kernels induces apoptosis and causes cell cycle arrest in cancer cells: an updated review. Anti-CancerAgents in Medicinal Chemistry, 18(12), 1650-1655. http://doi.org/10.2174/1871520618666180105161136

SIEGEL, R. L., MILLER, K. D., JEMAL, A. 2018. Cancer statistics, 2018. CA A Cancer Journal for Clinicians, 68(1), 7-30. http://doi.org/10.3322/caac.21442 TANWAR, B., MODGIL, R., GOYAL, A. 2019. Effect of detoxification on biological quality of wild apricot (Prunus armeniaca L.) kernel. Journal of Science and Food Agriculture, 99(2), 517-528. https://doi.org/10.1002/jsfa.9209 ZHOU, C., QIAN, L., MA, H., YU, X., ZHANG, Z., QU, W., ZHANG, X., XIA, W. 2012. Enhancement of amygdalin activated with $\beta$-D-glucosidase on HepG2 cellsproliferation and apoptosis. Carbohydrate Polymers, 90(1), 516-523. http://doi.org/10.1016/j.carbpol.2012.05.073 